\title{
CORROSION BEHAVIOR OF LOW-ALLOY STEEL USED FOR FLEXIBLE PIPES EXPOSED TO A SEAWATER ENVIRONMENT
}

\author{
KOROZIJA MALO LEGIRANEGA JEKLA ZA FLEKSIBILNE CEVI, \\ IZPOSTAVLJENE MORSKI VODI
}

\author{
Zhenguang $\mathrm{Liu}^{{ }^{*}}$, Xiuhua $\mathrm{Gao}^{2}$, Linxiu $\mathrm{Du}^{2}$, Jianping $\mathrm{Li}^{2}$, Xiaonan Wang ${ }^{3}$, Xiaowei Zhou ${ }^{1}$ \\ ${ }_{1}^{1}$ Jiangsu University of Science and Technology, School of Material Science and Engineering and National Demonstration Center for \\ Experimental Materials Science and Engineering Education, no. 2, Mengxi Road, Jingkou District, Zhenjiang 212003, China \\ ${ }^{2}$ Northeastern University, State Key Laboratory of Rolling and Automation, no. 3-11, Wenhua Road, Heping District, Shenyang 110819, China \\ ${ }^{3}$ Soochow University, Shagang School of Iron and Steel, no. 8, Jixue Road, Xiangcheng District, Suzhou 215021, China
}

Prejem rokopisa - received: 2018-03-21; sprejem za objavo - accepted for publication: 2018-10-18

doi:10.17222/mit.2018.051

\begin{abstract}
An immersion experiment was carried out to illustrate the corrosion behavior of low-alloy steel used for flexible pipes in a seawater environment in terms of corrosion kinetics, corrosion phases, surface morphology, cross-sectional morphology and elemental distribution. The experimental results show that the corrosion rate with an exponential format is linear with respect to the corrosion time with an exponential format. The main corrosion phases are goethite $(\alpha-\mathrm{FeOOH})$, lepidocrocite $(\gamma-\mathrm{FeOOH})$, iron oxide $\left(\mathrm{Fe}_{2} \mathrm{O}_{3}\right)$ and magnetite $\left(\mathrm{Fe}_{3} \mathrm{O}_{4}\right)$. Corrosion products become denser and thicker with the increasing corrosion time. $\mathrm{Cr}$-rich compounds are the first to be formed on the coupon surfaces. The effects of the alloying elements on the corrosion products are different. Chromium is rich in the area near the steel substrate. Iron, oxygen and molybdenum are homogeneously distributed throughout the corrosion products.
\end{abstract}

Keywords: corrosion behavior, low-alloy steel, flexible pipe, seawater

Avtorji so izvajali preizkuse potapljanja fleksibilnih cevi iz malo legiranega jekla v morsko vodo, da bi ugotovili njihovo odpornost proti koroziji z vidika kinetike korozije, nastajanja korozijskih faz, morfologije površine in preseka cevi ter porazdelitve elementov. Preizkusi so pokazali, da je hitrost korozije eksponentno odvisna od časa. Glavne korozijske faze so getit $(\alpha-\mathrm{FeOOH})$, lepidokrokit $(\gamma-\mathrm{FeOOH})$, hematit $\left(\mathrm{Fe}_{2} \mathrm{O}_{3}\right)$ in magnetit $\left(\mathrm{Fe}_{3} \mathrm{O}_{4}\right)$. Čim dlje je cev $\mathrm{v}$ vodi, tem bolj narašča debelina in gostota korozijskih produktov. Najprej nastajajo s $\mathrm{Cr}$ bogate faze. Vplivi različnih legiranih elementov na korozijo so različni. Krom je največ v območju blizu jekla. Železo, kisik in molibden pa so homogeno porazdeljeni po korozijskih produktih.

Ključne besede: korozija, malo legirano jeklo, fleksibilne cevi, morska voda

\section{INTRODUCTION}

The fact that our precious resources of oil and gas on land are being increasingly consumed and that their quantity is decreasing due to continuous exploitation is an intractable problem. However, the resources of oil and gas in the oceans are rich. Thus, it is necessary to exploit the oil and gas in the oceans to resolve the energy challenge. A flexible pipe is one of the promising solutions used in the oceans to transport oil and gas from the fields to the consumers. ${ }^{1-3}$ Flexible pipes consist of the inner carcass, the inner sheath, the pressure armor layer, the tensile armor layer and the outer sheath. The armor layers are made of low-alloy steels, sustaining the high pressure during the transportation process of oil and gas. Low-alloy steel is susceptible to corrosion when a flexible pipe is used in the ocean environment because it is inevitable that low-alloy steel is in contact with the seawater. In addition, many studies confirm that $\mathrm{Cl}^{-}$ions in seawater are some of the most detrimental electrolyte ions, threatening the safety of low-alloy steel. ${ }^{4-6}$ Thus, it

*Corresponding author e-mail: zgliu@just.edu.cn is necessary to study the corrosion behavior of low-alloy steel used for flexible pipes exposed to the seawater environment.

The corrosion behavior of low-alloy steel exposed to a water environment depends on several factors, such as chemical elements, corrosion environment or the style of the electrolyte solution. Chromium is usually added to the steel substrate to improve the corrosion resistance. The electrochemical characteristics of the low-alloy steel containing chromium, such as the corrosion current density, open circuit potential and impedance, are better than those of the low-alloy steel without chromium. The corrosion rate of the low-alloy steel containing chromium is also excellent. ${ }^{7-9}$ Molybdenum is also one of the common elements used in low-alloy steel. Molybdenum accumulates in the inner layer of the corrosion products, producing $\mathrm{MoO}_{3}$, which promotes the formation of compact corrosion products. ${ }^{10}$ Nickel can have a positive effect on the corrosion potential and is beneficial for the formation of a homogeneous and compact inner layer. ${ }^{11,12}$ Corrosion behavior of low-alloy steel exhibits different characteristics in different corrosion environments. The corrosion electrolyte is one of the key 
factors. ${ }^{13-16}$ For the seawater corrosion, the structure and style of the corrosion products have significant effects on the corrosion behavior. In general, there are four kinds of corrosion products when steel is exposed to water, namely, goethite $(\alpha-\mathrm{FeOOH})$, akaganetie $(\beta-\mathrm{FeOOH})$, lepidocrocite $(\gamma$-FeOOH$)$ and feroxyhyte $(\delta$-FeOOH$)$. Meanwhile, oxide compounds, such as hematite $\left(\alpha-\mathrm{Fe}_{2} \mathrm{O}_{3}\right)$, maghemite $\left(\beta-\mathrm{Fe}_{2} \mathrm{O}_{3}\right)$, magnetite $\left(\mathrm{Fe}_{3} \mathrm{O}_{4}\right)$ and ferrihydrite $\left(\mathrm{Fe}_{5} \mathrm{HO}_{8} \cdot 4 \mathrm{H}_{2} \mathrm{O}\right)$, can also be formed in certain environments. ${ }^{17-19}$ The alloying elements of the steel substrate influence the formation of corrosion products. Some studies demonstrate that $\mathrm{Cr}$-substituted goethite is observed. Nickel is beneficial for the formation of nanophasic or superparamagnetic $\alpha$-FeOOH. Silicon accelerates the formation of goethite with a small particle size, improving the corrosion resistance. ${ }^{20-22}$ In general, the corrosion behavior of the low-alloy steel exposed to atmospheric and marine conditions are investigated by many scholars. These studies provide fundamental data, illustrating the corrosion behavior of the low-alloy steel exposed to the seawater environment.

A flexible pipe is one of the promising pipes used for transporting oil and gas from the field in an ocean to the land. The corrosion phenomenon of the low-alloy steel used for armor layers is a serious problem because flexible pipes are used in the ocean environment and corrosion reduces the longevity of low-alloy steel. However, there are few reports about the corrosion behavior of the low-alloy steel used for the flexible pipes exposed to the seawater environment. The effect of the alloying elements on corrosion products is not clear either. Thus, it is necessary to study the corrosion behavior of the low-alloy steel used for armor layers to provide the basic data for a safe operation of flexible pipes and illustrate the effects of alloying elements on the formation of corrosion products. In this paper, the corrosion behavior is investigated using the immersion experiment in terms of the corrosion kinetics, corrosion phases, surface morphology, cross-sectional morphology and elemental distribution of corrosion products.

\section{EXPERIMENTAL PART}

The chemical composition of the designed low-alloy steel was C 0.07, Si 0.24, Mn 0.84, Cr 1.1, Mo 0.27 and the Fe balance. The designed steel was melted, hot-rolled and cold-rolled into a plate. The heat-treatment process of quenching and tempering was utilized to improve the microstructure and mechanical properties. The size of the tested coupons used in this experiment was $(40 \times 24$ $\times 4) \mathrm{mm}$. The surface of these coupons was sequentially ground with 240\#, 400\#, 600\# and 800\# silicon carbide paper. Distilled water and alcohol were used to remove dust and grease from the coupon surface, respectively. A balance with a precision of $0.01 \mathrm{mg}$ (Sartorius CP 2250D) was employed to obtain the original weight of these coupons $\left(\mathrm{m}_{1}\right)$. The electrolyte solution was 0.598 mol kg-1 $\mathrm{NaCl}$. The $\mathrm{NaCl}$ used in this experiment was the analytical reagent and water was distilled.

An immersion experiment was used to simulate a practical environment. Six immersion durations, namely 192 h (8 d), 384 h (16 d), 768 h (32 d); 1536 h (64 d), $3072 \mathrm{~h}(128 \mathrm{~d})$ and $4320 \mathrm{~h}$ (180 d), were chosen to study the corrosion behavior of low-alloy steel. The experimental temperature was $25{ }^{\circ} \mathrm{C}$. For each duration, three replicated coupons were used. The chemical-cleaning method was employed to remove the corrosion products from these corroded coupon surfaces. The composition of the cleaning solution was $40 \mathrm{~mL} 37(x / \%)$ hydrochloric acid, $20 \mathrm{~g}$ urotropine and $500 \mathrm{~mL}$ distilled water. After removing the corrosion products, these coupons were weighed again to obtain their final weight after the removal of the corrosion products $\left(\mathrm{m}_{2}\right)$.

D/max 2400 X-ray diffraction (XRD) with the $\mathrm{CuK}_{\alpha}$ radiation and a step of $0.04^{\circ}$ was used to detect the styles of the corrosion products. The MDI Jade software equipped with data base PDF-2 (2004) identified the style by matching standard peaks. A Quanta 600 scanning electron microscope (SEM) equipped with EDX was employed to show the macroscopic and microscopic surface morphologies of the corrosion products. Microscopy set-ups included an extra high tension of $20 \mathrm{kV}$, a working distance of $10 \mathrm{~mm}$ and a second electron image. The corrosion products on the coupon surfaces were fixed with epoxy. The morphology characteristics of the cross-sectional and elemental distribution of the corrosion products were tested using a JEOL-8530F electron probe analyzer (EPMA) with a voltage of $20 \mathrm{kV}$, a working distance of $11 \mathrm{~mm}$ and a backscattered electron image.

\section{RESULTS AND DISCUSSION}

\subsection{Corrosion kinetics}

The corrosion rate generally reflects the corrosion behavior of metal materials. In this experiment, the corrosion rate $(\mathrm{CR})$ is characterized using the weight loss. The corrosion rate is calculated according to Equation (1):

$$
C R=\frac{87,600 \Delta m}{t \rho S}
$$

where $\Delta m$ presents the mass loss $(\mathrm{g}), \Delta m=\mathrm{m}_{1}-\mathrm{m}_{2} ; t$ is the immersion duration (h); $\rho$ is the density of steel, $\left(\mathrm{g} / \mathrm{cm}^{3}\right) ; S$ is the surface area of the tested coupons exposed to corrosion $\left(\mathrm{cm}^{2}\right)$. Figure 1 shows the corrosion kinetics curve of the designed low-alloy steel exposed to a simulated seawater environment. The corrosion process during the tested time consists of three stages. In the first stage (192-384 h), the value of the corrosion rate drops sharply (from $0.093 \mathrm{~mm} \mathrm{y}^{-1}$ to $0.072 \mathrm{~mm} \mathrm{y}^{-1}$ ) and the corrosion rate is high, attributing to a few corrosion products on the coupon surface. In the second stage $(384-1536 \mathrm{~h})$, there is a mild 


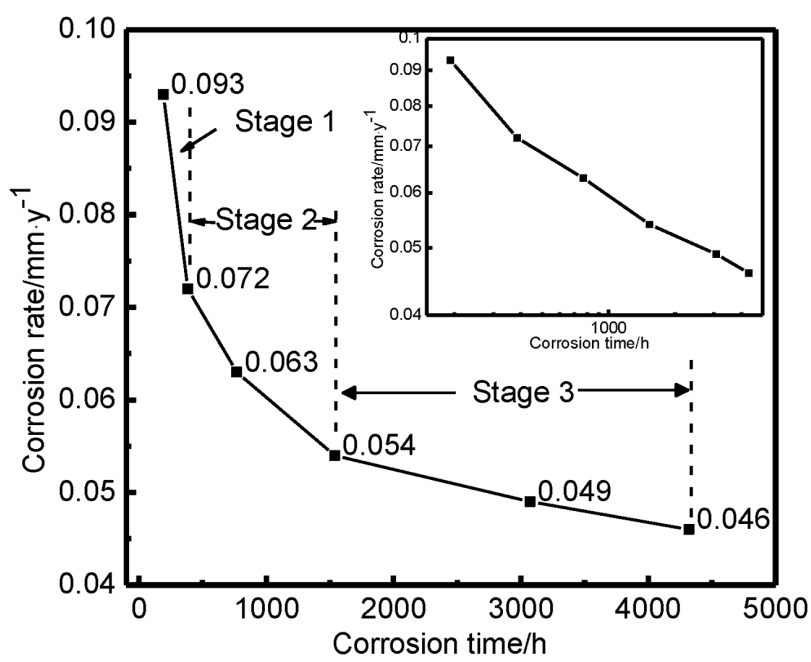

Figure 1: Corrosion kinetics curve

decreasing trend in the corrosion rate. In the third stage, the corrosion rate changes to some extent. The final corrosion rate is $0.046 \mathrm{~mm} \mathrm{y}^{-1}$, after these coupons are corroded for $4320 \mathrm{~h}$ (nearly half a year). The value of the corrosion rate from this experiment meets the expected value for the flexible pipes used in the ocean environment. In our experiment, the corrosion time increases in the exponential format. The insert graph in
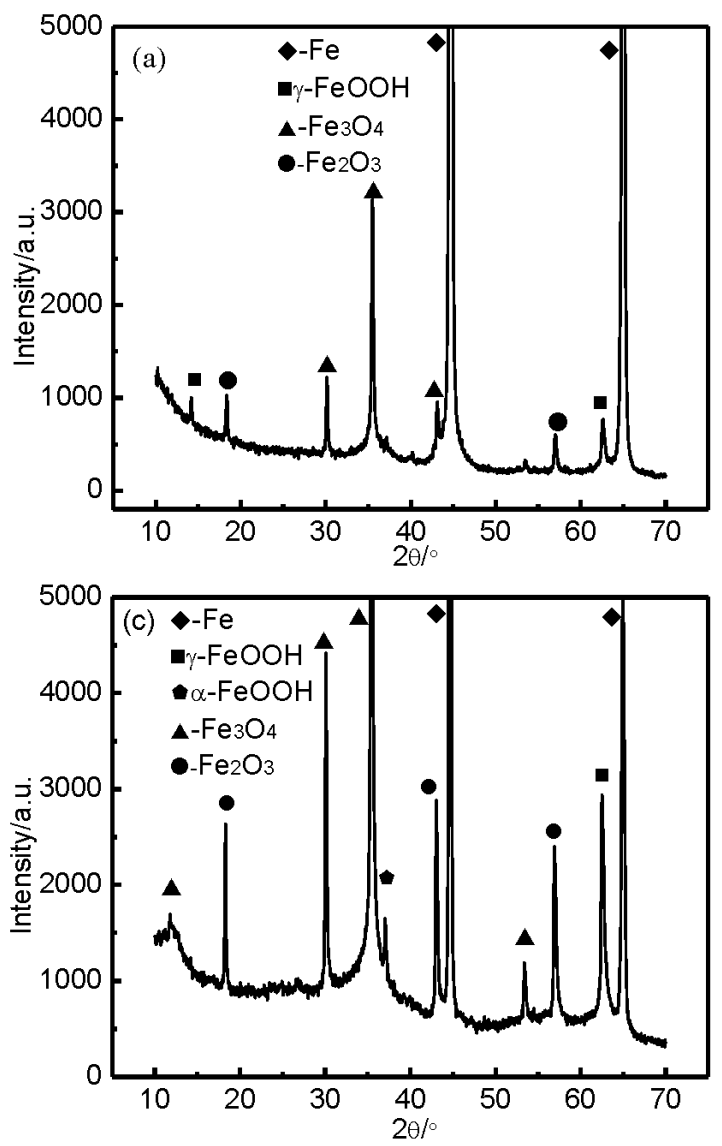

Figure 1 reflects the relationship of the corrosion time with the exponential format and the corrosion rate with the exponential format, conveniently illustrating the essence of the corrosion process. The insert graph clearly demonstrates that the corrosion rate with the exponential format is approximately linear with respect to the corrosion time with the exponential format. In other words, the corrosion rate and corrosion time meet the following function format:

$$
\lg C R=\mathrm{A}+\mathrm{B} \lg t
$$

where $C R$ is the corrosion rate $\left(\mathrm{mm} \mathrm{y}^{-1}\right) ; \mathrm{A}$ and $\mathrm{B}$ are constants; $t$ presents the corrosion time (h). In general, Figure 1 shows that the corrosion rate decreases with the increasing corrosion time, indicating that the corrosion resistance rises gradually. The changing characteristics of the corrosion products on the coupon surfaces explain this phenomenon, which will be discussed in the following section.

\subsection{Corrosion phases}

For corrosion science, the electrochemical process is a reaction of the materials and corrosion ions in the electrolyte solution. Corrosion products allow an important method, i.e., the study of electrochemical reactions during the corrosion process because corrosion
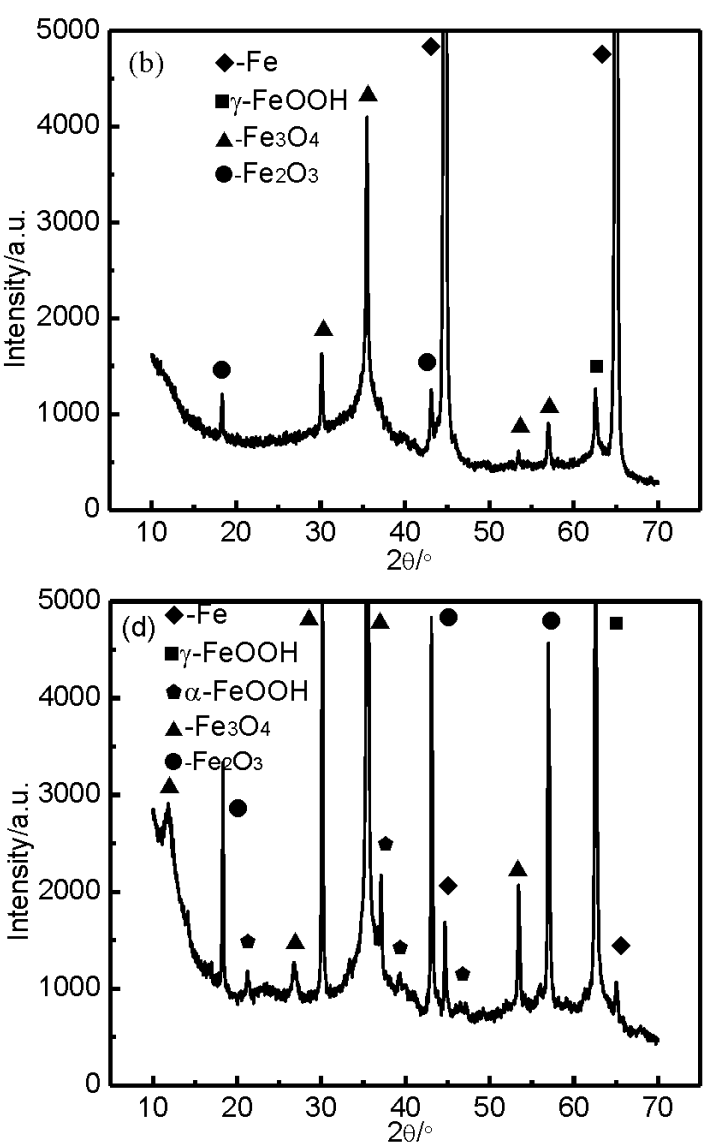

Figure 2: Corrosion phases on the coupon surfaces after different immersion durations: a) 192 h, b) 384 h, c) 1536 h, d) 4320 h 
products are the results of chemical reactions. The styles of the corrosion products detected with XRD are shown in Figure 2. Figure 1 indicates that the corrosion process generally consists of three stages. Thus, the corrosion phases of four critical immersion durations, namely 192 h, 384 h, 1536 h and 4320 h, are shown. Figures 2a and $\mathbf{2 b}$ show that the main corrosion products of the first stage are $\gamma$-FeOOH, $\mathrm{Fe}_{2} \mathrm{O}_{3}$ and $\mathrm{Fe}_{3} \mathrm{O}_{4}$. Meanwhile, the steel substrate is also detected on the coupon surfaces. In the second and third stages (Figures 2c and 2d), $\alpha$-FeOOH, $\gamma$-FeOOH, $\mathrm{Fe}_{2} \mathrm{O}_{3}$ and $\mathrm{Fe}_{3} \mathrm{O}_{4}$ are detected. Figure 2 shows that the intensity of the critical peaks of the corrosion products increases and the intensity of the iron peak decreases with the increasing corrosion time, indicating that more corrosion products are formed on the coupon surfaces. Thus, the corrosion rate (Figure 1) decreases continuously because the corrosion products act as a shield preventing the corrosion ions from the electrolyte solution from accessing the steel substrate. The electrochemical reaction is inhibited to some extent due to the physical barrier.

\subsection{Surface morphology}

The corrosion process consists of surface and interface reactions. The basic mechanism of the corrosion resistance shows us that compact and dense corrosion products are formed on the coupon surfaces, physically segregating the material and the corrosion condition and being similar to the corrosion-resistance mechanism of a surface coating. ${ }^{23-26}$ The macroscopic surface morphol- ogy reflects the changing trend in the corrosion products during the immersion process. Figure 3 exhibits the macroscopic surface morphology of the corroded coupons after different immersion durations. After the 192-h immersion (Figure 3a), corrosion products are formed on the coupon surface. There are three kinds of surface morphologies, marked as A, B and C. The steel substrate is observed on the coupon surface (position $\mathrm{C}$ ), which is consistent with the XRD result (Figure 2a). Figure $3 \mathbf{b}$ shows that the macroscopic-surface-morphology characteristics of the corrosion products after the 384-h immersion are similar to those of the corrosion products after the 192-h immersion (Figure 3a). The corrosion products forming a cluster are observed on the coupon surface after the 384-h immersion (position D in Figure 3b). With the increasing corrosion time (Figure 3c), compact corrosion products (position E) are formed. After the tested coupons are immersed into the electrolyte solution for $1536 \mathrm{~h}$ (Figure 3d), the coupon surfaces are nearly completely covered with white corrosion products, and the grey corrosion products are also observed. Figure 3e shows that the surface morphologies of the corrosion products are divided into two kinds, marked as $\mathrm{G}$ and $\mathrm{H}$. After the tested coupons are being corroded in the electrolyte solution for nearly half a year (Figure 3f), dense and compact corrosion products are formed. Figure 3 indicates that the quantity of corrosion products rises with the increasing corrosion time and that the surface morphology structure of the corrosion products becomes more compact and denser. These charac-
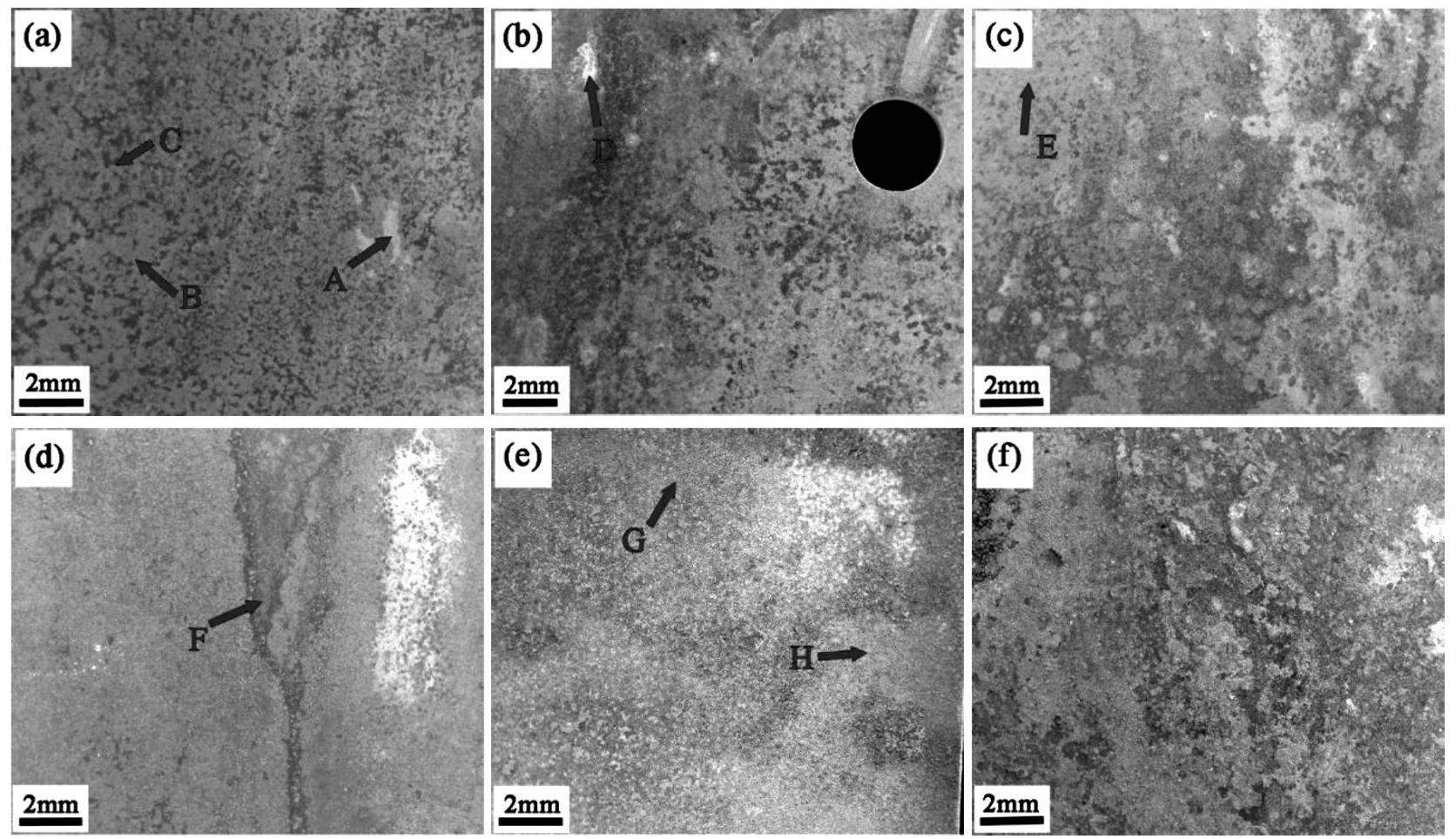

Figure 3: Macroscopic surface morphology of the corrosion products formed after different immersion durations: a) 192 h, b) 384 h, c) 768 h, d) $1536 \mathrm{~h}, \mathrm{e}) 3072 \mathrm{~h}, \mathrm{f}) 4320 \mathrm{~h}$ 

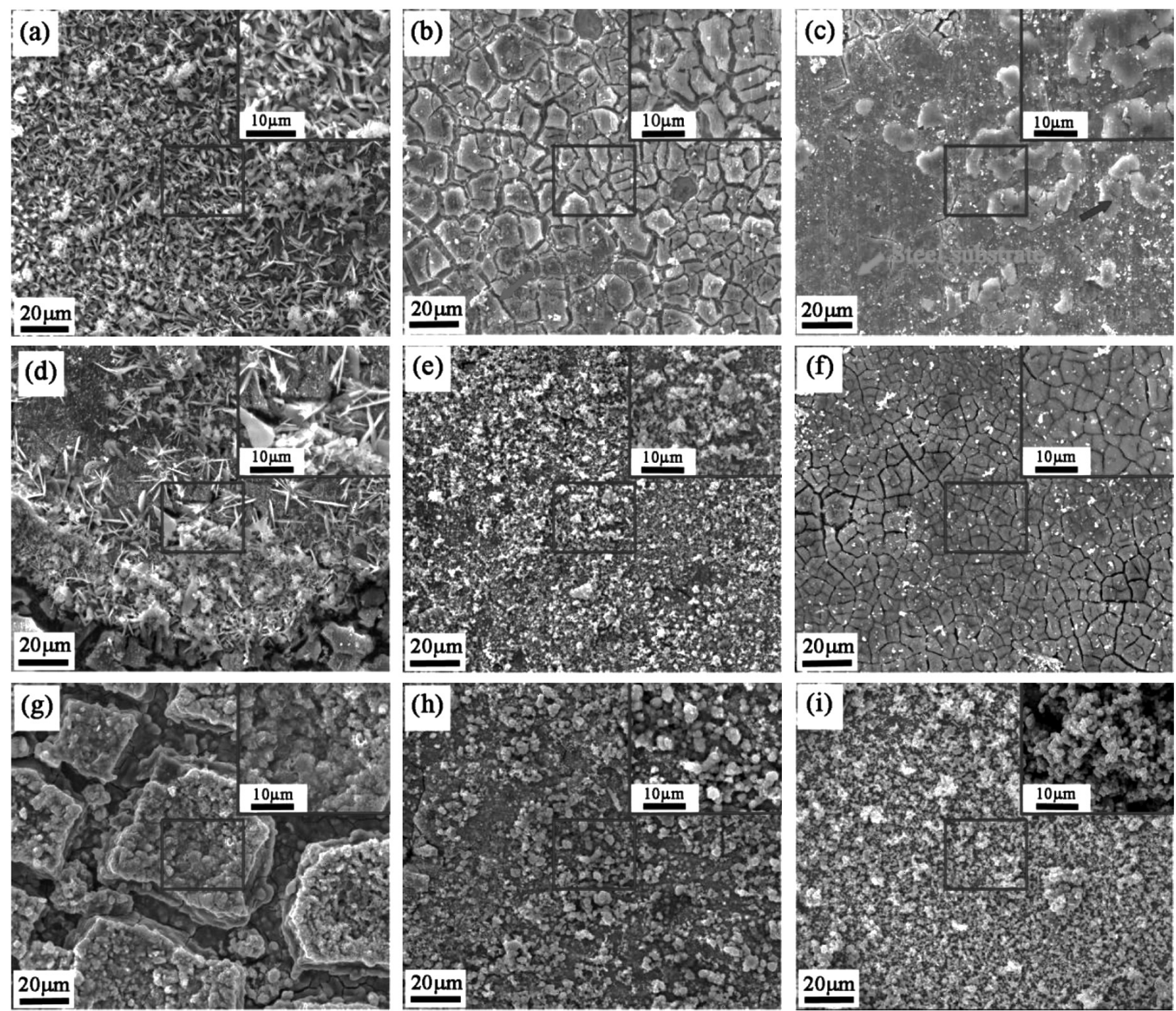

Figure 4: Microscopic surface morphology of the corrosion products formed after different immersion durations: a-c) 192 h, d) 384 h, e) 768 h, f) $1536 \mathrm{~h}, \mathrm{~g}, \mathrm{~h}) 3072 \mathrm{~h}$, i) $4320 \mathrm{~h}$

teristics are beneficial for the corrosion resistance because the corrosion products preclude the permeation of corrosion ions throughout the electrolyte solution. Thus, the corrosion rate decreases gradually with the prolonging corrosion time. The corrosion rate is in line with the changing trend in the macroscopic surface morphology.

The microscopic surface morphology exhibits the structure characteristics of the corrosion products in detail. Figure 4 shows microscopic graphs of the corrosion products formed after different immersion durations. The insert graph is a magnified figure of a rectangular region marked with a blue line to make the microscopic structure clear. Figures $\mathbf{4 a}$ to $\mathbf{4 c}$ are the microscopic morphologies of the corrosion products formed after the 192-h immersion, corresponding to positions A, B and C in Figure 3a, respectively. Figure $4 \mathbf{a}$ shows that the corrosion products are acicular. The XRD result (Figure 2a) reveals that the corrosion phases of the corrosion products after the 192-h immersion are $\gamma$ - $\mathrm{FeOOH}, \mathrm{Fe}_{2} \mathrm{O}_{3}$, $\mathrm{Fe}_{3} \mathrm{O}_{4}$; the steel substrate is also found. Figure 5a includes the EDX analysis result for the acicular corrosion products from Figure 4a. It shows that the chemical compositions of the corrosion products consist of iron and oxygen. Thus, the acicular corrosion products from Figure 4a are $\gamma$-FeOOH according to the XRD and EDX results from this study and other researchers' studies about the surface morphology characteristics of the corrosion products formed in a water corrosion environment. ${ }^{27,28}$ Figure 4 b reveals compact corrosion products with crackings. The structure of the corrosion products in the electrolyte solution is complete and the crackings appear due to the dehydration after the coupons are taken out of the electrolyte solution, which is confirmed by other scholars. ${ }^{29,30}$ Figure $4 \mathbf{c}$ shows a bare surface. Figures $\mathbf{5 b}$ and $\mathbf{5} \mathbf{c}$ correspond to the EDX results for the corrosion products shown in Figures $\mathbf{4 b}$ and $\mathbf{4 c}$, respectively. These results indicate that the chemical compo- 
sitions of the corrosion products previously formed on the coupon surfaces are chromium, iron, oxygen, carbon and chlorine. The typical element is chromium. Thus, these compact corrosion products shown in Figures $\mathbf{4 b}$ and $\mathbf{4 c}$ are $\mathrm{Cr}$-rich compounds according to the surface morphology characteristics and chemical compositions, which is also confirmed by our previous studies. ${ }^{13,17,31}$

The formation process for the Cr-rich compounds of low-alloy steel is similar to that of stainless steel. A special property of chromium is a low metal-metal bond strength with a high metal-oxygen bond strength. This chemical property is beneficial for the breaking of the surface metal-metal bonds during the early stages of spontaneous prepassivation. ${ }^{32,33}$ Thus, Cr-rich compounds are the first to be formed on the coupon surfaces. These corrosion products primarily prevent the permeation of the corrosion ions in the electrolyte solution and protect the steel substrate. Thus, the corrosion rate drops sharply after the 192-h immersion (Figure 1). Figure 4c shows that the steel substrate is observed on the coupon surface. The bubble-like corrosion products marked with a blue arrow are $\mathrm{Fe}_{3} \mathrm{O}_{4}$. Figure 3 shows that the main macroscopic surface morphologies after the immersions of $384 \mathrm{~h}, 768 \mathrm{~h}, 1536 \mathrm{~h}, 3072 \mathrm{~h}$ and $4320 \mathrm{~h}$ are similar to that after the 192-h immersion (Figure 3a).

Figures $\mathbf{4 a}$ to $\mathbf{4 c}$ also present the microscopic surface morphology of the corrosion products formed after other immersion durations. Some typical surface morphology characteristics of the corrosion products formed after different immersion durations are revealed in Figure 4. Figure 4d shows the microscopic surface morphology of the corrosion products in a cluster marked with $\mathrm{D}$ in Figure 3b (the 384-h immersion). The structure of these corrosion products is acicular and lamellar. These corrosion products are formed on the previous corrosion products with crackings. These corrosion products also include $\gamma$-FeOOH based on the surface morphology and the XRD result (Figure $2 \mathbf{b}$ ). Figure $4 \mathbf{e}$ (the magnified surface of the corrosion products marked with $\mathrm{E}$ from Figure 3c) reveals that the corrosion products formed after the 768-h immersion appear to have a cotton shape. The style of these corrosion products is $\alpha-\mathrm{FeOOH}$ according to other scholars' studies and the XRD results from this study (Figure 2). The structure of $\alpha-\mathrm{FeOOH}$ is solid and dense, which is beneficial for the corrosion resistance ${ }^{17,18,27,28}$ Figure $4 \mathbf{f}$ corresponds to the microscopic surface morphology of the corrosion products marked with $\mathrm{F}$ in Figure 3d (the 1536-h immersion). The structure of the corrosion products from Figure $\mathbf{4 f}$ is more compact and denser, and its crackings become narrower. The structure of the corrosion products formed during the second stage of the corrosion process (Figures $\mathbf{4 e}$ and $\mathbf{4 f}$ ) is solid. Thus, the corrosion rate of the second stage decreases steadily with the prolonging corrosion time (Figure 1).

Figures $\mathbf{4 g}$ and $\mathbf{4 h}$ show magnified graphs of the corrosion products marked as $\mathrm{G}$ and $\mathrm{H}$ in Figure $\mathbf{3 e}$ (the 3072-h immersion). Figure $\mathbf{4 g}$ shows that the structure of the corrosion products is free of the capillaries, through which the corrosion ions from the electrolyte solution diffuse into the steel substrate. The thickness of the corrosion products becomes larger. The thicker corrosion products preclude the electrochemical reactions between iron and the corrosion electrolyte. Figure 4h reveals that the corrosion products have a cotton shape and their size is small. The corrosion products shown in Figure $4 \mathbf{h}$ consist of $\alpha-\mathrm{FeOOH}$ according to the other scholars' studies and the XRD results from this study (Figure 2). Figure 4i shows a typical surface morphology of the corrosion products after the 4320-h immersion. The size of the corrosion products becomes smaller. The EDX result shows that the corrosion products shown in Figure 4i contain chromium. Many studies indicate that chromium promotes the formation of corrosion products at the nanoscale after a long-term immersion. ${ }^{34,35}$ Thus, the fine corrosion products are observed on the coupon surface after a nearly half-a-year immersion. Figures $\mathbf{4 g}$ to $\mathbf{4 i}$ show that the structure of the corrosion products of the third stage is dense and fine, improving the corrosion resistance. The structure of the corrosion products of the third stage changes a little. Thus, the corrosion rate of the third stage decreases to a small degree. Macroscopic and microscopic surface morphologies (Figures 3 and 4) demonstrate that more corrosion products are formed on the coupon surfaces and that the structure becomes denser with the increasing
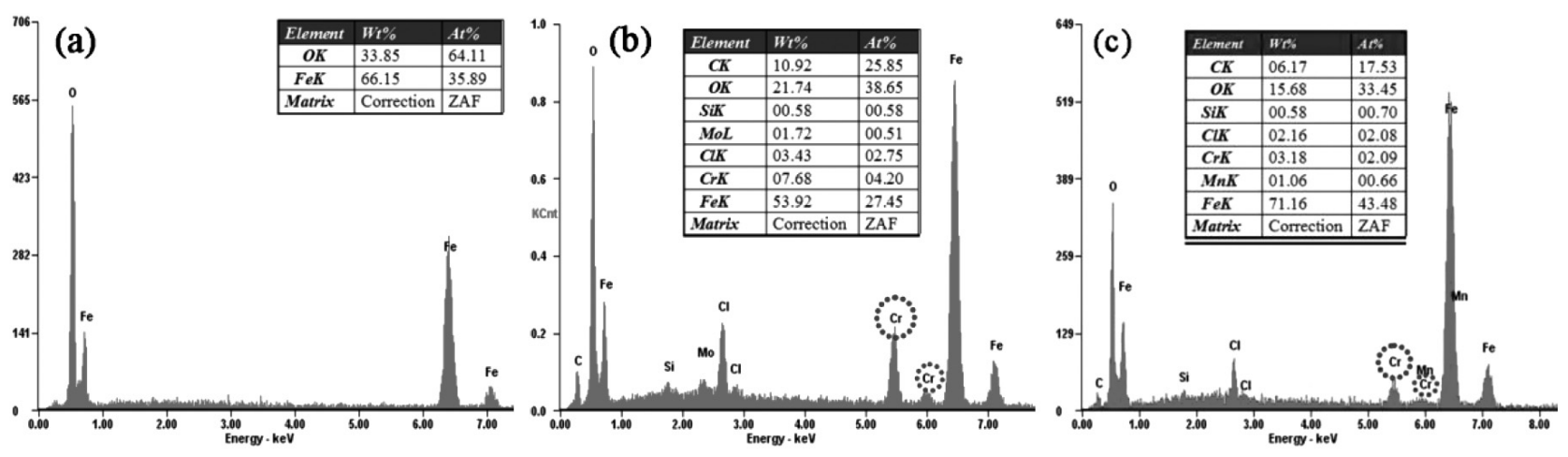

Figure 5: EDX results for different corrosion products. Figures $\mathbf{5 a}$ to $\mathbf{5 c}$ correspond to the results of the corrosion products shown in Figures $\mathbf{4 a}$ to $4 \mathbf{c}$, respectively 


\section{Z. LIU et al.: CORROSION BEHAVIOR OF LOW-ALLOY STEEL USED FOR FLEXIBLE PIPES EXPOSED}

corrosion time, which is consistent with the XRD result (Figure 2). The corrosion rate decreases gradually due to the changing trend of the corrosion products (Figure 1). The anodic and cathodic reactions shown by reactions (3)-(5) are suppressed. anodic reaction: $\mathrm{Fe} \rightarrow \mathrm{Fe}^{2+}+2 \mathrm{e} \mathrm{Fe} \rightarrow \mathrm{Fe}^{3+}+3 \mathrm{e}$

cathodic reaction: $\mathrm{O}_{2}+2 \mathrm{H}_{2} \mathrm{O}+4 \mathrm{e} \rightarrow 4 \mathrm{OH}^{-}$

total reaction: $2 \mathrm{Fe}+\mathrm{O}_{2}+2 \mathrm{H}_{2} \mathrm{O} \rightarrow 2 \mathrm{Fe}(\mathrm{OH})_{2}$
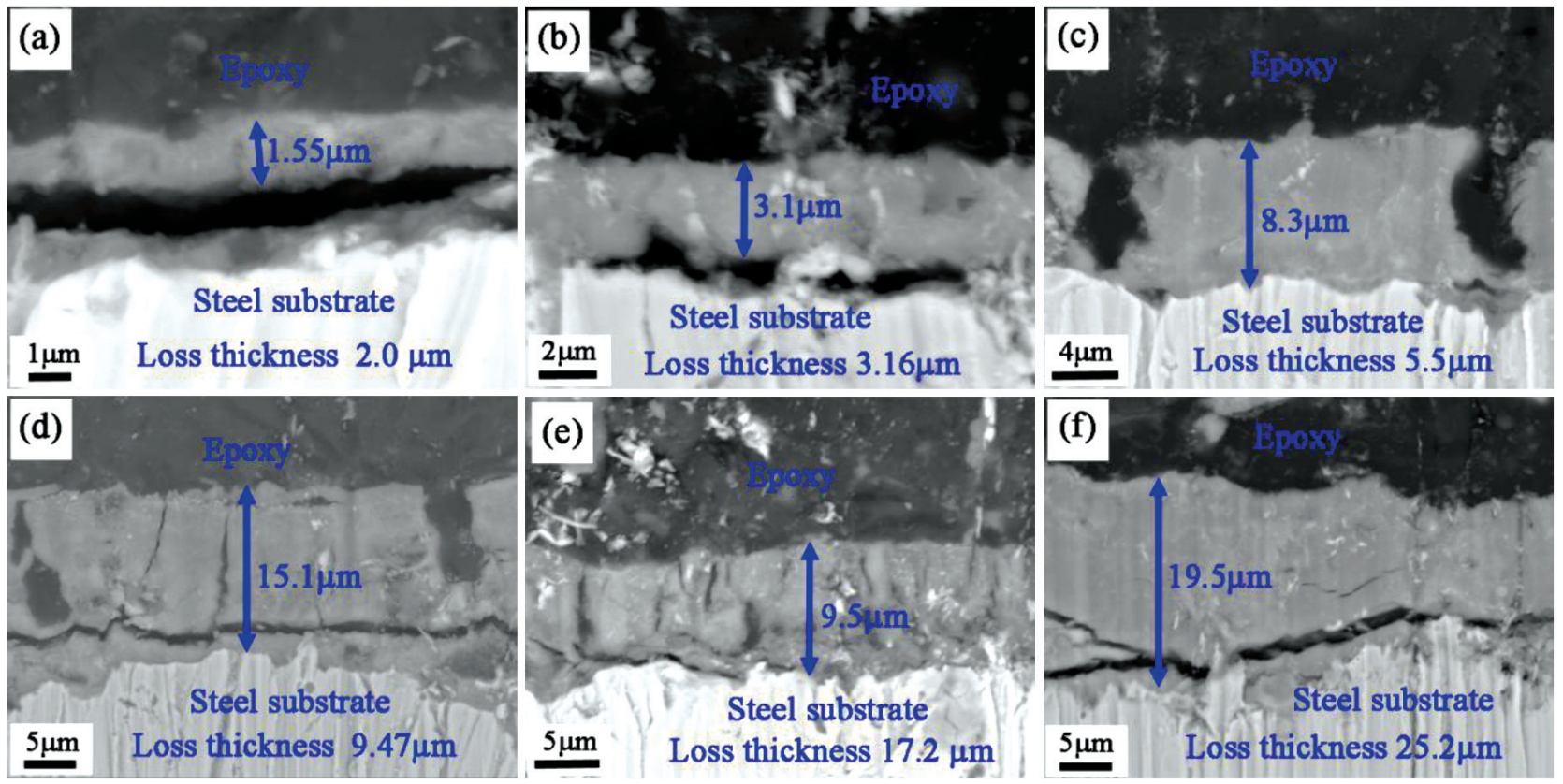

Figure 6: Cross-sectional morphology of the corrosion products after different immersion durations: a) 192 h, b) 384 h, c) 768 h, d) 1536 h, e) $3072 \mathrm{~h}, \mathrm{f}) 4320 \mathrm{~h}$. The value of rust thickness is the average.
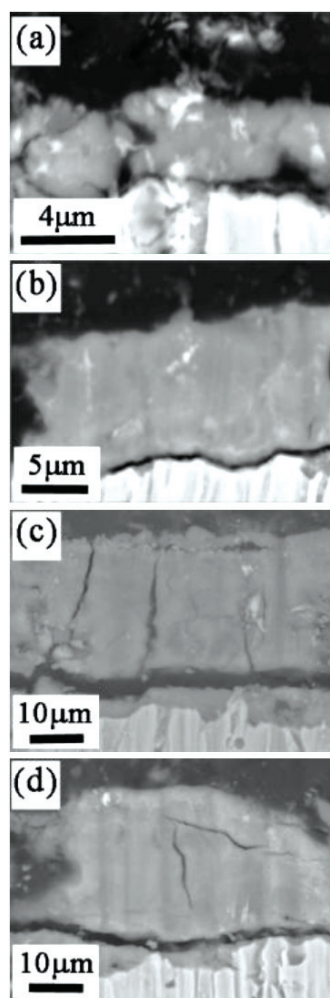
$10 \mu \mathrm{m}$
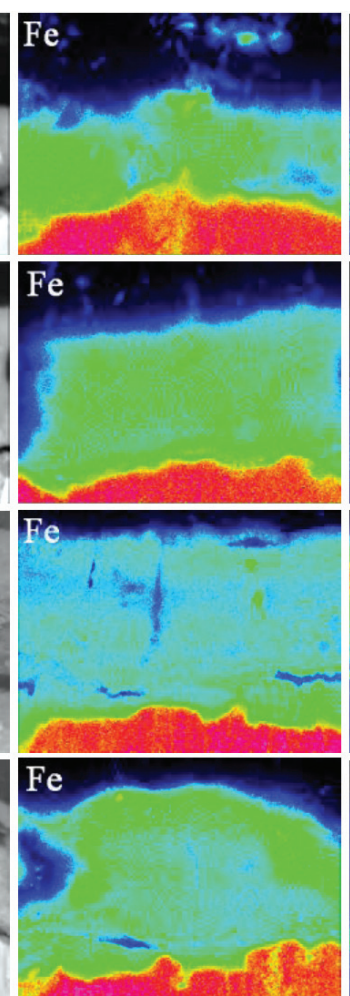

Level low
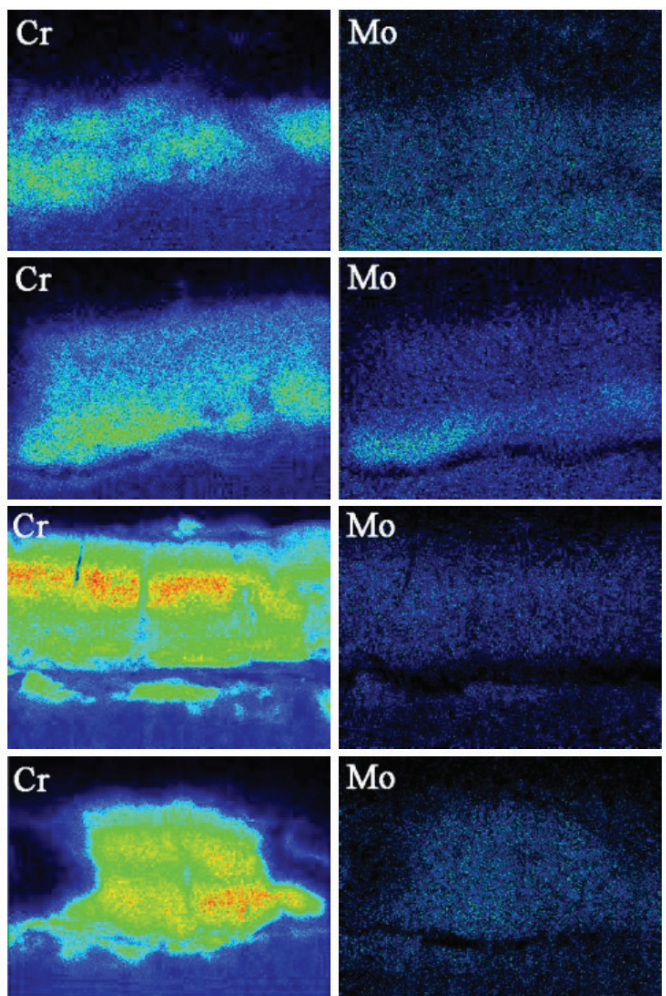

Level high
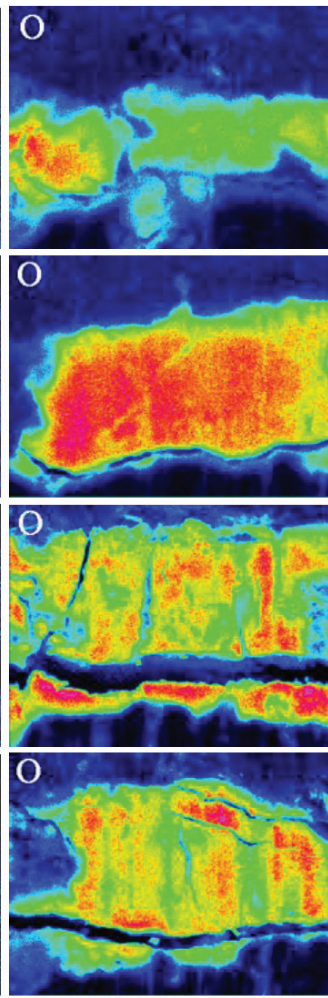

Figure 7: Elemental distribution of the corrosion products formed after different immersion durations: a) $192 \mathrm{~h}$, b) $384 \mathrm{~h}$, c) $1536 \mathrm{~h}$, d) $4320 \mathrm{~h}$ 


\subsection{Cross-sectional morphology}

Macroscopic and microscopic surface morphology characteristics of the corrosion products exhibit the structure of the corrosion products. Cross-sectional morphology observed using EPMA is another way to study the structure and thickness of corrosion products in detail. Figure 6 shows the thickness of the corrosion products formed after different immersion durations. The loss-thickness values for the steel substrate calculated from the corrosion rate are listed in Figure 6. After the 192-h immersion (Figure 6a), a thin film with a thickness of $\sim 1.55 \mu \mathrm{m}$ is formed on the coupon surface. Figure 6b shows that the thickness of the corrosion products increases to $3.1 \mu \mathrm{m}$ after the 384-h immersion. After the 768-h immersion (Figure 6c), the thickness is $\sim 8.3 \mu \mathrm{m}$. Crackings are observed in the cross-sectional morphology of the corrosion products shown in Figure 6c. This characteristic is consistent with the microscopic surface morphology (Figure 4). The crackings are also found in the cross-sectional morphology of the corrosion products formed after the 1536-h immersion (Figure 6d). The thicknesses of the corrosion products after the 1536-h, 3072-h and 4320-h immersions are $\sim 15.1 \mu \mathrm{m}$, $9.5 \mu \mathrm{m}$ and $19.5 \mu \mathrm{m}$, respectively. In general, Figure 6 shows that the thickness of the corrosion products increases with the prolonging corrosion time and that the structure becomes denser, which is in line with the surface morphology (Figure 4). The thick and compact corrosion products improve the corrosion resistance because the diffusion distance for corrosion ions is longer and the diffusion channel becomes narrower. Thus, the corrosion rate decreases versus the corrosion time.

\subsection{Elemental distribution}

For the corrosion science, alloying elements in the steel substrate have a key effect on the corrosion behavior. Thus, the elemental distribution of the corrosion products is observed using EPMA to study the effect of the alloying elements in the designed low-alloy steel on the corrosion process. Figure 7 reveals the elemental distribution of the corrosion products formed after the 192-h, 384-h, 1536-h and 4320-h immersions, and the transient points of the corrosion process. Figure 7 shows that iron is homogeneously distributed in the corrosion products formed in different immersion periods, indicating that the chemical process involving the iron ions dissolving from the steel substrate continuously occurs. Chromium tends to accumulate in the area near the steel substrate. This phenomenon confirms that $\mathrm{Cr}$-rich compounds are formed on the coupon surfaces at an early stage (Figures $\mathbf{4 b}$ and $\mathbf{4 c}$ ). Thus, it is confirmed that Cr-rich compounds are the first to be formed on the coupon surfaces. Molybdenum is uniformly dispersed in the corrosion products. The distribution of oxygen is also homogeneous.

\section{CONCLUSIONS}

A flexible pipe is one of the promising pipes used for transporting oil and gas from the depth of an ocean to the land. Armor layers of flexible pipes are made of low-alloy steel, which suffers from seawater corrosion when used in the ocean environment. In this paper, the corrosion behavior of the low-alloy steel used for flexible pipes is studied using immersion experiments. The corrosion behavior is characterized by the corrosion kinetics, corrosion phases, macroscopic/microscopic surface morphology, cross-sectional morphology and elemental distribution of the corrosion products. The experimental results show that the corrosion rate decreases with the increasing corrosion time. The corrosion rate with an exponential format is linear with respect to the corrosion time with an exponential format. The main corrosion phases are goethite $(\alpha-\mathrm{FeOOH})$, lepidocrocite $(\gamma$-FeOOH$)$ and magnetite $\left(\mathrm{Fe}_{3} \mathrm{O}_{4}\right)$. Cr-rich compounds are the first to be formed on the coupon surfaces. The corrosion products become denser and thicker with the prolonging corrosion time. Fine corrosion products are formed after a long-term immersion. Chromium accumulates in the area near the steel substrate while iron, molybdenum and oxygen are homogeneously dispersed.

\section{Acknowledgment}

The authors are grateful for the financial support from the Natural Science Foundation of the Jiangsu Province (BK 20180984, 20150467), Doctoral Scientific Research Foundation of the Jiangsu University of Science and Technology (1062931702), the National High Technology Research and Development Program of China (2015AA03A501), and the Natural Science Foundation of China (NSFC, 51804219, 51305285, 51605203).

\section{REFERENCES}

${ }^{1}$ N. H. Østergaard, A. Lyckegaard, J. H. Andreasen, On modelling of lateral buckling failure in flexible pipe tensile armour layers, Marine Structure, 27 (2012) 1, 64-81, doi:10.1016/j.marstruc.2012.03.005

${ }^{2}$ J. Łuczko, A. Czerwiński, Nonlinear three-dimensional dynamics of flexible pipes conveying fluids, Journal of Fluid and Structure, 70 (2017), 235-260, doi:10.1016/j.jfluidstructs.2017.02.002

${ }^{3}$ Y. Bai, T. Liu, W. D. Ruan, W. Chen, Mechanical behavior of metallic strip flexible pipe subjected to tension, Composite Structures, 170 (2017), 1-10, doi:10.1016/j.compstruct.2017.02.044

${ }^{4}$ Y. F. Lu, J. H. Dong, W. Ke, Effects of $\mathrm{Cl}^{-}$ions on the corrosion behaviour of low alloy steel in deaerated bicarbonate solution, Journal of Materials Science Technology, 32 (2016) 4, 341-384, doi:10.1016/j.jmst.2015.11.015

${ }^{5}$ Y. Zuo, L. Yang, Y. J. Tan, Y. S. Wang, J. M. Zhao, The effects of thioureido imidazoline and $\mathrm{NaNO}_{2}$ on passivation and pitting corrosion of $\mathrm{X} 70$ steel in acidic $\mathrm{NaCl}$ solution, Corrosion Science, 120 (2017), 99-106, doi:0.1016/j.corsci.2016.12.015

${ }^{6} \check{C}$. Donik, I. Paulin, M. Jenko, Influence of MnS inclusion on the corrosion of austenitic stainless steels, Mater. Tehnol., 44 (2010) 2 , $67-72$ 
${ }^{7}$ G. Q. Su, X. H. Gao, D. Z. Zhang, C. S. Cui, L. X. Du, C. Yu, J. Hu, Z. G. Liu, Offset effect of chromium on the adverse impact of manganese in a low-C medium-Mn steel with reversed austenite in the neutral salt spray condition, Corrosion, 73 (2017) 11, 1367-1380, doi: $10.5006 / 2433$

${ }^{8}$ Q. F. Xu, K. W. Gao, W. T. Lv, X. L. Pang, Effects of alloyed Cr and $\mathrm{Cu}$ on the corrosion behavior of low-alloy steel in a simulated groundwater solution, Corrosion Science, 102 (2016), 114-124, doi:10.1016/j.corsci.2015.09.025

${ }^{9}$ R. Wang, S. J. Luo, M. Liu, Y. N. Xue, Electrochemical corrosion performance of $\mathrm{Cr}$ and $\mathrm{Al}$ alloy steels using a J55 carbon steel as base alloy, Corrosion Science, 85 (2014), 270-279, doi:10.1016/ j.corsci.2014.04.023

${ }^{10}$ X. M. Xiao, Y. Peng, C. Y. Ma, Z. L. Tian, Effects of alloy element and microstructure on corrosion resistant property of deposited metals of weathering steel, Journal of Iron and Steel Research, International, 23 (2016) 2, 171-177, doi:10.1016/S1006-706X (16)30030-9

${ }^{11}$ X. Q. Cheng, Y. W. Tian, X. G. Li, C. Zhou, Corrosion behavior of nickel-containing weathering steel in simulated marine atmospheric environment, Materials and Corrosion, 65 (2014) 10, 1033-1037, doi:10.1002/maco.201307447

${ }^{12}$ W. M. Liu, Q. J. Zhou, L. S. Li, Z. J. Wu, F. B. Cao, Z. F. Gao, Effect of alloy element on corrosion behavior of the huge crude oil storage tank steel in seawater, Journal of Alloys and Compounds, 598 (2014), 198-204, doi:10.1016/j.jallcom.2014.01.181

${ }^{13}$ Z. G. Liu, X. H. Gao, L. X. Du, J. P. Li, P. Li, C. Yu, R. D. K. Misra, Y. X. Wang, Comparison of corrosion behaviour of low-alloy pipeline steel exposed to $\mathrm{H}_{2} \mathrm{~S} / \mathrm{CO}_{2}$-saturated brine and vapour-saturated $\mathrm{H}_{2} \mathrm{~S} / \mathrm{CO}_{2}$ environments, Electrochimica Acta, 232 (2017), 528-541, doi:10.1016/j.electacta.2017.02.114

${ }^{14}$ D. Z. Zhang, X. H Gao, G.. Q. Su, L. X. Du, Z. G. Liu, J. Hu, Corrosion behavior of low-C medium-Mn steel in simulated marine immersion and splash zone environment, Journal of Materials Engineering and Performance, 26 (2017) 6, 2599-2607, doi:10.1007/ s11665-017-2723-6

${ }^{15}$ A. Cesen, T. Kosec, A. Legat, V. Bokan-Bosiljkov, Corrosion properties of different forms of carbon steel in simulated concrete water, Mater. Technol., 48 (2014) 1, 51-57

${ }^{16}$ Y. L. Huang, X. M. Yu, Q. C. Zhang, R. De Marco, Corrosion performance of high strength low alloy steel AISI 4135 in the marine splash zone, Electrochemistry, 85 (2017) 1, 7-12, doi:10.5796/ electrochemistry.85.7

${ }^{17}$ Z. G. Liu, X. H. Gao, L. X. Du, J. P. Li, P. Li, Corrosion behaviour of low-alloy steel with titanium addition exposed to seawater environment, International Journal of Electrochemical Science, 11 (2016) 8, 6540-6551, doi:10.20964/2016.08.25

${ }^{18}$ H. Cano, D. Neff, M. Morcillo, P. Dillmann, I. Diaz, D. de la Fuente, Characterization of corrosion products formed on $\mathrm{Ni} 2.4 \mathrm{wt} \%-\mathrm{Cu} 0.5$ wt $\%-C r 0.5$ wt $\%$ weathering steel exposed in marine atmospheres, Corrosion Science, 87 (2014), 438-451, doi:10.1016/j.corsci. 2014.07.011

${ }^{19}$ Q. C. Zhang, J. S. Wu, J. J. Wang, W. L. Zheng, J. G. Chen, A. B. Li, Corrosion behaviour of weathering steel in marine atmosphere, Materials Chemistry and Physics, 77 (2002), 603-608, doi:10.1016/ S0254-0584(02)00110-4

${ }^{20}$ M. Yamashita, H. Miyuki, H. Nagano, T. Misawa, Compositional gradient and ion selectivity in $\mathrm{Cr}$-substituted goethite consisting the final stable protective rust layer on a weathering steel, $13^{\text {th }}$ International Corrosion Congress, Melbourne, 1996, Paper 020

${ }^{21}$ I. Diaz, H. Cano, D. de la Fuente, B. Chico, J. M. Vega, M. Morcill, Atmospheric corrosion of Ni-advanced weathering steels in marine atmospheres of moderate salinity, Corrosion Science, 76 (2013), 348-360, doi:10.1016/j.corsci.2013.06.053

${ }^{22}$ G. J. A. Mejía, J. Antonissen, C. A. Palacio, E. De Grave, Effects of $\mathrm{Si}$ as alloying element on corrosion resistance of weathering steel, Corrosion Science, 59 (2012), 198-203, doi:10.1016/j.corsci. 2012.03.004

${ }^{23}$ X. W. Zhou, C. Ouyang, Anodized porous titanium coated with $\mathrm{Ni}-\mathrm{CeO}_{2}$ deposits for enhancing surface toughness and wear resistance, Applied Surface Science, 405 (2017), 476-488, doi:10.1016/ j.apsusc.2017.02.034

${ }^{24}$ X. Y. Lu, X. G. Feng, Y. Zuo, C. B. Zheng, S. Lu, L. Xu, Evaluation of the micro-arc oxidation treatment effect on the protective performance of a Mg-rich epoxy coating on AZ91D magnesium alloy, Surface and Coatings Technology, 270 (2015), 227-235, doi:10.1016/j.surfcoat.2015.02.052

${ }^{25}$ X. L. Shi, L. L. Xu, T. B. Le, G. H. Zhou, C. B. Zheng, K. J. Tsuru, K. Ishikawa, Partial oxidation of TiN coating by hydrothermal treatment and ozone treatment to improve its osteoconductivity, Materials Science and Engineering C, 59 (2016), 542-548, doi:10.1016/j.msec.2015.10.024

${ }^{26}$ C. B. Zheng, X. Chen, ZrMoN film on 304 stainless steel as bipolar plates for PEMFCs using physical-vapor-deposition (PVD) technology, Mater. Technol., 51 (2017) 4, 699-705, doi:10.17222/mit. 2016.316

${ }^{27}$ Y. T. Ma, Y. Li, F. H. Wang, The effect of $\beta$-FeOOH on the corrosion behavior of low carbon steel exposed in tropic marine environment, Materials Chemistry and Physics, 112 (2008), 844-852, doi:10.1016/j.matchemphys.2008.06.066

${ }^{28}$ Y. T. Ma, H. Li, F. H. Wang, Corrosion of low carbon steel in atmospheric environments of different chloride content, Corrosion Science, 51 (2009), 997-1006, doi:10.1016/j.corsci.2009.02.009

${ }^{29}$ S. Q. Guo, L. N. Xu, L. Zhang, W. Chang, M. X. Lu, Corrosion of alloy steels containing $2 \%$ chromium in $\mathrm{CO}_{2}$ environment, Corrosion Science, 63 (2012), 246-258, doi:10.1016/j.corsci.2012.06.006

${ }^{30}$ Y. Xie, L.N. Xu, C.L. Gao, W. Chang, M.X. Lu, Corrosion behaviour of novel $3 \% \mathrm{Cr}$ pipeline steel in $\mathrm{CO}_{2}$ top-of-line corrosion environment, Materials and Design, 36 (2012), 54-57, doi:10.1016/j.matdes. 2011.11.003

${ }^{31}$ Z. G. Liu, X. H. Gao, J. P. Li, L. X. Du, C. Yu, P. Li, X. L. Bai, Corrosion behaviour of low-alloy martensite steel exposed to vapour-saturated $\mathrm{CO}_{2}$ and $\mathrm{CO}_{2}$-saturated brine conditions, Electrochimica Acta, 213 (2016), 842-855, doi:10.1016/j.electacta.2016. 08.024

${ }^{32}$ C. Donik, A. Kocijan, Comparison of the corrosion behavior of austenitic stainless steel in seawater and in a $3.5 \% \mathrm{NaCl}$ solution, Mater. Technol.,, 48 (2014) 6, 937-942

${ }^{33}$ M. Torkar, A. Kocijan, R. Celin, J. Burja, B. Podgornik, Metallographic investigation and corrosion resistance of welds of ferritic stainless steels, Mater. Technol.,, 50 (2016) 5, 829-834, doi:10.17222/mit.2016.059

${ }^{34}$ M. Yamashita, H. Miyuki, Y. Matsuda, H. Nagano, T. Misawa, The long term growth of the protective rust layer formed on weathering steel by atmospheric corrosion during a quarter of a century, Corrosion Science, 36 (1994), 283-299, doi:10.1016/0010-938X (94)90158-9

${ }^{35}$ D. C. Cook, S. J. Oh, R. Balasubramanian, M. Yamashita, The role of goethite in the formation of the protective corrosion layer on steels, Hyperfine Interaction, 122 (1999), 1-2, 59-70, doi:10.1023/ A: 1012685320582 